Research article

\title{
Assessment of the ecotoxicity of phytotreatment substrate soil as landfill cover material for in-situ leachate management
}

\author{
Francesco Garbo ${ }^{\mathrm{a}}$, Alberto Pivato ${ }^{\mathrm{b}, *}$, Barbara Manachini ${ }^{\mathrm{c}}$, Carlo Giovanni Moretto ${ }^{\mathrm{d}}$, \\ Maria Cristina Lavagnolo \\ a DII - Department of Industrial Engineering, University of Padova, Via Marzolo 9, 35131, Padova, Italy \\ ${ }^{\mathrm{b}}$ DICEA - Department of Civil, Environmental and Architectural Engineering, University of Padova, Via Marzolo 9, 35131, Padova, Italy \\ ${ }^{\mathrm{c}} S A A F$ - Department of Agricultural, Food and Forest Sciences, University of Palermo, Viale delle Scienze 13, 90128, Palermo, Italy \\ ${ }^{\mathrm{d}}$ ARPAV - Inlad Water Observatory, via Rezzonico 41, 35131, Padova, Italy
}

\section{A R T I C L E I N F O}

\section{Keywords:}

Landfill leachate phytotreatment

Closed landfills

Substrate soil chemical characterization

Ecotoxicological bioassays

Environmental legislation

\begin{abstract}
A B S T R A C T
Phytotreatment capping in closed landfills is a promising, cost-effective, in situ option for sustainable leachate treatment and might be synergistically coupled with energy crops to produce renewable energy (e.g.: biodiesel or bioethanol). This study proposes to use $0.30 \mathrm{~m}$ of soil as growing substrate for plants cultivated on the temporary cover of closed landfills. Once the leachate phytotreatment process is no longer required, $0.70 \mathrm{~m}$ of the same soil would be added to attain the final top cover configuration. This solution would entail saving the costs of excavation and backfilling. However, worsening of the initial soil quality due to potential contaminant transfer from the liquid to the solid matrix must be avoided because EU legislation (such as that in Italy) fixes concentration limits for contaminants in soil. In this research, samples of soil used as substrate in a lab-scale leachate phytotreatment test with sunflowers were analysed to provide chemical characterization before, during, and at the end of the experiment. The results showed that the phytotreatment activity did not increase initial contaminant concentrations. These results are reinforced by those from ecotoxicological bioassays in which Eisenia fetida (earthworms), Lepidium sativum (cress), Folsomia candida (collembola), and Caenorhabditis elegans and Steinernema carpocapsae (nematodes) were used. It was observed that, by the end of the experiment, the substrate soil did not affect the earthworms, collembola and nematode behaviour, or the growth of cress.
\end{abstract}

\section{Introduction}

Landfilling is still considered the final element of most waste management strategies, so as to close the material usage loop. However, among others, the main problems linked to landfills are leachate management and the damage to the landscape that these waste masses can create (Cossu and Williams, 2015). In fact, one of the most onerous items of expenditure is the leachate management (Oloibiri et al., 2017), which is stored and then, most of times, treated ex situ often using highly sophisticated technologies such as reverse osmosis, evaporation systems and membrane bioreactors (Di Maria et al., 2018; Saleem et al., 2018). In addition, landfills are not typically accepted by citizens: following the "NIMBY" (Not In My Back Yard) principle (Ma and Hipel, 2016), they consider them dangerous accumulations of waste. These oppositions could be minimized by the utilization of energy crops growing on the top of closed landfills, not only for leachate phytotreatment purposes but also for renewable energy generation, offering a pleasant view of the site (Lavagnolo et al., 2016) and enhancing the process of environmental restoration (Pivato et al., 2018a) at the same time. The landfill leachate, which is collected and re-circulated to the top of the closed landfill, could be phytotreated on a portion of the surface area with little slope. Additionally, this would make it possible to save the huge amounts of water necessary to irrigate these types of plants (Garbo et al., 2017). Energy crops can be used effectively to treat landfill leachate because they are able to resist the organic and inorganic contaminants (Agostini et al., 2003; Brunetti et al., 2011; January et al., 2008; Marchiol et al., 2007; Schnoor et al., 1995; Tang et al., 2016). These plants were tested by several authors (Akinbile et al., 2012; Fraser et al., 2004; Hasselgren, 1992; Ma et al., 2016) who demonstrated their high efficiency in contaminant removal due to the synergic effects of the plants and the microorganisms living in the soil. The final objective of energy crop cultivation is the production of renewable energy: bioethanol from ligneous biomass, biodiesel from oleaginous crops and biogas from the biomass feedstock (Di Maria and

\footnotetext{
* Corresponding author.

E-mail address: alberto.pivato@unipd.it (A. Pivato).
} 
Temporary top cover

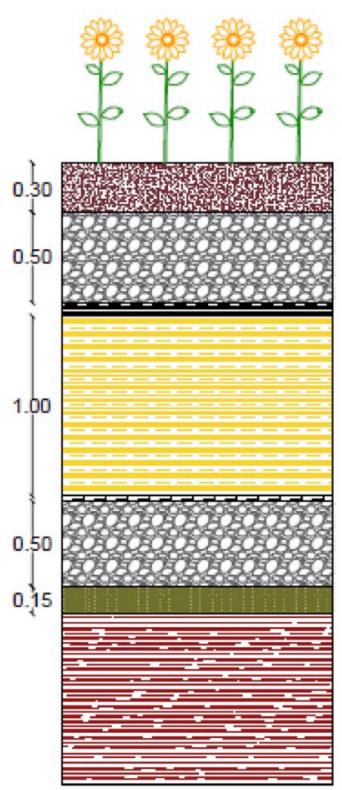

Final top cover

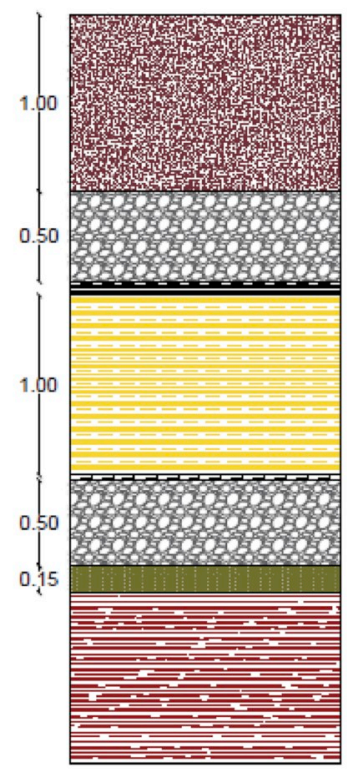

\section{Final top cover according} to national regulation

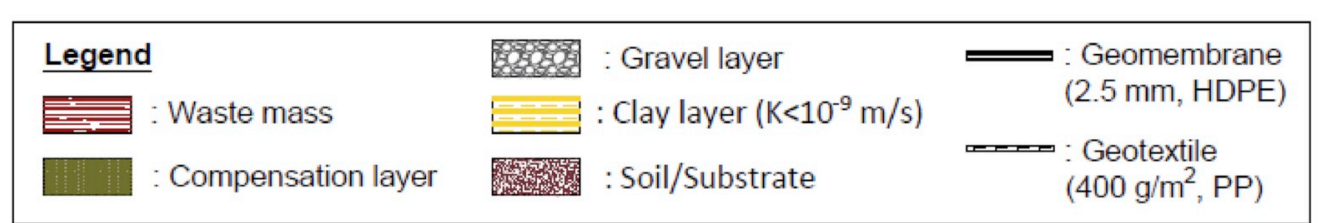

Fig. 1. Comparison between temporary and final top cover proposed in this article and final top cover prescribed by the current Italian legislation.

Sisani, 2017; Lavagnolo et al., 2017; Pandey et al., 2016). Garbo et al. (2017) and Lavagnolo et al. (2016) have already considered the use of oleaginous crops (e.g. sunflower, soybean, rapeseed) on the top of a landfill for leachate phytotreatment and biodiesel production. They reported good results, achieving efficiencies higher than $80 \%$ for Chemical Oxygen Demand (COD) reduction, and removal of more than 70\% of total nitrogen $(\mathrm{N})$ and more than $95 \%$ of total phosphorous $\left(\mathrm{P}_{\text {tot }}\right)$. Moreover, a significant fraction of the leachate volume was removed by natural evapo-transpiration (Garbo et al., 2017; Lavagnolo et al., 2016).

The EU Directive 1999/31/CE mandates the competent authority (region or province) to prescribe surface sealing of the landfill only if a potential hazard to the environment is recognized. On the other hand, the Italian transposition (D. Lgs. 36/2003) of the EU Directive and some regional regulations (e.g. DGR Lombardia n. X/2461/2014) prescribe a mandatory impermeable final top cover, aimed at minimizing the infiltration of liquids into the landfill body. Therefore, a phytotreatment basin built on the landfill final top cover is discouraged by the current Italian laws and regulations. To comply with the current national legislation, the following scenario was proposed (Fig. 1): the plants, irrigated with the leachate, are cultivated during the temporary cover period in $0.30 \mathrm{~m}$ of substrate soil, which is required for root development. At the end of the phytotreatment process, an additional layer of soil $(0.70 \mathrm{~m})$ is added to reach the final top cover configuration called for in D. Lgs. 36/2003 (at least $1.00 \mathrm{~m}$ of natural soil as superficial layer). In this manner, the costs of excavation and backfilling can be limited because the substrate soil used for phytotreatment is simply covered with the same type of soil. Moreover, to minimize leachate infiltration in the landfill body, an additional $0.50 \mathrm{~m}$ thickness of clay, for a total of $1.00 \mathrm{~m}$, is also considered; in fact, the legislation (D. Lgs. $36 / 2003$ ) requires a minimum thickness of $0.50 \mathrm{~m}$. Therefore, the proposal for the final configuration is - from bottom to top - a $0.15 \mathrm{~m}$ compensation layer, $0.50 \mathrm{~m}$ of gravel to permit landfill gas drainage and collection, a $1.00 \mathrm{~m}$ layer of clay (instead of $0.50 \mathrm{~m}$ ), with a permeability $k$ less than $10^{-9} \mathrm{~m} / \mathrm{s}$, a High-Density PolyEthylene (HDPE) geomembrane, a geotextile, $0.50 \mathrm{~m}$ of gravel to drain the water and $1.00 \mathrm{~m}$ of natural soil. Fig. 1 shows that the proposed final cover has the same configuration as the final cover now prescribed by law, except for the clay layer.

In this research, experiments were performed using the substrate soil on which sunflowers were cultivated. Sunflowers were irrigated with leachate to represent the scenario of leachate phytotreatment on the top of the landfill. One of the critical points of full-scale application could be the substrate soil quality at the end of phytotreatment period. Based on our literature review, there are no studies in which the wetlands growing medium has been chemically characterised and compared with the reference values set by the current legislations. However, a chemical analysis for a substance-based approach is not sufficient because the soil is a very complex living matrix including soil fauna along with microorganisms (EFSA, 2017; Manachini et al., 2009). These can absorb elements such as carbon and nitrogen, to degrade organic compounds and to amass stock substances in the form of humus (EFSA, 2017; Jacomini et al., 2000). Thus, it is necessary to consider also ecotoxicological analysis for a matrix-based approach (Pivato et al., 2017). Ecotoxicological testing involves the study of the effects of toxic compounds present in the soil on representative organisms (APAT, 2004; Hennebert, 2017).

In the past, some studies considered the use of earthworms, nematodes, and the germination of seeds as bio-indicators to determine the toxicity of a soil. For example, Dawson et al. (2007) considered earthworms and seed germination assays as indicators to assess the ecological health of soils from a former gas-works site undergoing various remediation treatments. Holmstrup et al. (2010) considered the effects of natural stresses during ecotoxicological analysis using earthworms and nematodes. Pivato et al. (2018b; 2016; 2014) utilized Eisenia fetida earthworms and Folsomia candida collembola to investigate the quality of compost and digestate for possible use in agriculture. There are no 
references, however, reporting the ecotoxicological characterization of a substrate soil used for landfill leachate phytotreatment with energy crops.

In this work, chemical and ecotoxicological characterisations were conducted on the substrate soil before, during and after the leachate phytotreatment to determine if the substances contained in the leachate, or formed during the phytotreatment process, cause significant worsening of the soil quality. The concentrations of contaminants in the substrate soil were compared with reference values (screening values) for potentially contaminated sites defined in Table 1 of Annex 5 to Part IV of D. Lgs. 152/06 (soil for public, private and residential green areas in column A; soil for commercial and industrial activities in column B) to check if contamination occurred.

Chemical characterization was combined and reinforced by a series of ecotoxicological tests that were conducted using the following suitable vulnerable model species (EFSA, 2017): Lepidium sativum (cress), Eisenia fetida (earthworms), Folsomia candida (collembola) and the nematodes Caenorhabditis elegans and Steinernema carpocapsae, in which the potential toxicity of the substrate soil samples was assessed based on the growth and biological development of the organisms.

\section{Materials and methods}

\subsection{Experimental design}

The tested samples were collected from a lab-scale phytotreatment test, performed according to the experimental design described by Lavagnolo et al. (2016) and Garbo et al. (2017). Four $45 \mathrm{~L}$ polyethylene tanks, with a surface area of $0.16 \mathrm{~m}^{2}$, were used. All tanks were placed in a controlled climatic chamber in which a $14 \mathrm{~h}$ photoperiod with $300 \mu \mathrm{mol} \mathrm{m}{ }^{-2} \cdot \mathrm{s}^{-1}$ light intensity was imposed. The mean air temperature was maintained at $24^{\circ} \mathrm{C}\left(\mathrm{MIN}=17^{\circ} \mathrm{C}, \mathrm{MAX}=35^{\circ} \mathrm{C}\right)$. To the four tanks were added - from the bottom to the top $-8 \mathrm{~cm}$ of gravel (20-30 mm diameter) for drainage, a small net to avoid clogging of the drainage system and $30 \mathrm{~cm}$ of substrate soil (the scheme of the tanks is reported in Supplementary Material - Fig. S1). Four sunflowers were planted in each experimental unit. Based on previous experiences (Garbo et al., 2017), the number of plants was considered to be sufficient. After an initial acclimation period, lasting for 14 days, in which tap water was used, sunflowers were irrigated with a mixture containing water and an increasing amount of landfill leachate, as reported in Table 1. The applied Hydraulic Loading Rate (HLR) was $4.5 \mathrm{~mm} \mathrm{~d}^{-1}$. The irrigation was spread uniformly over the entire surface of each reactor. The leachate dose was increased gradually to adapt the plants to the increasing concentration of contaminants and to avoid sudden failure from potential phytotoxicity. The nitrogen concentration in the feed was used as a reference parameter in setting the irrigation timetable; previous studies had revealed that nitrogen exceeding $400 \mathrm{mg}-\mathrm{N}$ / L could produce a negative effect on plants (Garbo et al., 2017;

Table 1

Main characteristics of the irrigation water over the whole experimental period and the sampling timetable.

\begin{tabular}{llllll}
\hline Week & $\begin{array}{l}\text { HLR } \\
\left(\mathrm{mm} \cdot \mathrm{d}^{-1}\right)\end{array}$ & $\begin{array}{l}\text { Leachate } \\
\text { percentage }\end{array}$ & $\begin{array}{l}\text { COD inlet } \\
\left(\mathrm{mg} \cdot \mathrm{L}^{-1}\right)\end{array}$ & $\begin{array}{l}\mathrm{P} \text { inlet } \\
\left(\mathrm{mg} \cdot \mathrm{L}^{-1}\right)\end{array}$ & $\begin{array}{l}\mathrm{TKN} \text { inlet } \\
\left(\mathrm{mg} \cdot \mathrm{L}^{-1}\right)\end{array}$ \\
\hline \multicolumn{7}{l}{ Collection of initial substrate soil samples } \\
1 & 4.5 & $10 \%$ & 49 & 0.23 & 50 \\
2 & 4.5 & $20 \%$ & 98 & 0.46 & 100 \\
3 & 4.5 & $30 \%$ & 147 & 0.69 & 150 \\
4 & 4.5 & $40 \%$ & 196 & 0.92 & 200 \\
5 & 4.5 & $50 \%$ & 245 & 1.15 & 250 \\
Collection & of intermediate substrate soil samples (35 days from the beginning of the \\
\multicolumn{6}{l}{ test) } \\
6-10
\end{tabular}

Lavagnolo et al., 2016). Once a week, the tanks were drained through a valve at the bottom.

The substrate soil was the same in all the experimental units. The initial sample (initial substrate soil) was analysed before the start of the phytotreatment tests. After 35 days from the beginning, the substrate soil was excavated from two tanks, mixed, and analysed (intermediate substrate soil). The remaining two reactors were run until clear senescence of the sunflowers was reached (70 days from the beginning of the phytotreatment): then the plants were harvested, reactors were excavated, and the substrate soils were mixed and analysed (final substrate soil).

\subsection{Leachate characterization}

The leachate used in the experiment was collected from a sector of an operating landfill located in the North of Italy, in which residual waste from separate collection of Municipal Solid Waste (MSW) is disposed of. It was sampled once and analysed four times during the experiment to check whether the main parameters (e.g.: nitrogen) were changed over time. It was analysed according to the CNR-IRSA standard Italian analytical methods for liquid samples (CNR-IRSA, 29/2003). Its composition is reported in Supplementary Material - Table S1 and the results are consistent with the kind of waste landfilled.

\subsection{Substrate soil characterization}

\subsubsection{Texture characterization}

The substrate soil utilized for the lab-scale phytotreatment system was a locally available soil rich in sand. It was collected in the proximity of the research centre in which the experiments were performed, in the North-East of Italy. Long-term studies indicate that mixtures of soil and sand provide an optimal combination for phytotreatment systems (Lavagnolo et al., 2016; Stottmeister et al., 2003; Verakoon et al., 2013) because they provide sufficient air circulation, while at the same time guaranteeing proper root development. The texture was determined using the Bouyoucos Method (Bouyoucos, 1962) and, according to the soil taxonomy proposed by the USDA (USDA-NRCS, 1999), the substrate soil was classified as sandy loam (14\% clay, $10 \%$ silt, and $76 \%$ sand).

\subsubsection{Chemical characterization}

The chemical characterization determined the presence of chemical compounds in the three substrate soil samples, which were analysed in triplicate. The compounds analysed were compared to the reference values (columns A and B) reported in Table 1 of Annex 5 to Part IV of D. Lgs. 152/06, already mentioned in the Introduction. The chemical analysis was performed according to the EPA Hazardous Waste Test Methods (SW-846).

\subsubsection{Ecotoxicological characterization}

2.3.3.1. Lepidium sativum (cress) tests. Soil quality can be evaluated using plants as bio-indicators. In this case, Lepidium sativum (cress) was used, according to the APAT guidelines (APAT, 2004), due to its ability to reveal quickly the potential toxicity of the soil. The tests were performed using Petri dishes $(\varnothing=9 \mathrm{~cm})$. A mixture of $10 \mathrm{~g}$ of testsubstrate soil (e.g. final substrate soil) and artificial soil (quartz sand with more than $50 \%$ of particles between 50 and $200 \mu \mathrm{m}$ ) was added to each dish. Increasing concentrations of the test-substrate soil were used: 0 (control), 2, 3, 5, 7, 10, 20, 30, 50, 70, and 100\% (w/w referred to dry matter) to which deionized water was added to reach $100 \%$ of the Water Holding Capacity (WHC) of the mixture, plus $5 \mathrm{~mL}$. As suggested by the USEPA (2005), the test concentrations were chosen to follow a geometrical series, with an average ratio of 1.5. Two controls were used: one with just $5 \mathrm{~mL}$ of deionized water (as prescribed by the APAT guidelines) and another with $10 \mathrm{~g}$ of artificial soil and $5 \mathrm{~mL}$ deionized water. The latter was used to be consistent with the testing procedure, 
which is based on the use of $10 \mathrm{~g}$ of material. Ten seeds were placed in each dish on a filter paper on top of the media, and the dishes were covered using parafilm. Seeds available in the market for bioassays were used. The tests were conducted under standardized conditions: $25^{\circ} \mathrm{C}$ and complete darkness (0 lux). After $72 \mathrm{~h}$, the elongation of the emerged roots was measured. As prescribed by the APAT guidelines, each concentration (including the controls) was tested using four replicas. The results were expressed as percentage Germination Index (GI\%); each Germination Index (GI) was calculated by multiplying the number of germinated seeds with the mean root length of each plant, as follows:

$G I=n \cdot$ germinated seeds $\cdot$ mean roots length

The mean GI was calculated for each substrate soil sample $(\overline{G I})$ and control $\left(\bar{G} I_{C}\right)$ and the percentage GI (GI\%) was calculated as ratio between $\overline{G I}$ and $\bar{G} I_{C}$, as follows:

$G I \%=\frac{\overline{G I}}{\overline{G I}_{C}} \cdot 100$

2.3.3.2. Earthworms tests. The method adopted was a chronic test performed according to the OECD Guideline 222/2004. Ten Eisenia fetida adult earthworms were put in plastic containers (volume $1.2 \mathrm{~L}$ ) filled with $500 \pm 5 \mathrm{~g}$ of a mixture of artificial soil and test-substrate soils, at different concentrations (the same concentrations used for the cress tests). The artificial soil was composed of $70 \%$ sand, $20 \%$ clay and $10 \%$ peat $(\mathrm{w} / \mathrm{w})$, as prescribed by the OECD Guideline $222 / 2004$. Its WHC was adjusted to $40 \%$. The maximum WHC of the artificial soil was determined in accordance with the procedures described in Annex 2 of ISO 11274 (1998). The initial weight of the earthworms ranged from 0.3 to $0.9 \mathrm{~g}$. Soil mixtures and earthworms were placed in the containers and closed with holed plastic lids to prevent the worms from escaping, to permit air passage and to limit evaporation. The earthworms were fed weekly with $5 \mathrm{~g}$ of dried cow manure. The test was performed in a thermostatic room with a monitored temperature of $20 \pm 2{ }^{\circ} \mathrm{C}$, light-dark cycles L:D 16:8 ( $\mathrm{L}=400-800$ lux $)$. After 28 days (Day 28), earthworms were counted and weighted. As prescribed by the OECD guidelines, each concentration was tested in triplicate. The results were expressed as percentage Relative Survival (RS\%) and percentage Relative Growth (RG\%). They were both defined as the average variation between the final and the initial earthworm conditions and were normalized using the values found in the controls (with $0 \%$ test-substrate soil), as follow:

$R S=\frac{\text { final } \mathrm{n} \text {. of earthworms }}{\text { initial } \mathrm{n} \text {. of earthworms }}$

$R G=\frac{\text { final earthworms weight }}{\text { initial earthworms weight }}$

The mean RS was calculated for each substrate soil sample $(\overline{R S})$ and control $\left(\overline{R S}_{C}\right)$ and the percentage RS (RS\%) was calculated as ratio between $\overline{R S}$ and $\overline{R S_{C}}$, as follows:

$R S \%=\frac{\overline{R S}}{\overline{R S}_{C}} \cdot 100$

The mean RG was calculated for each substrate soil sample $(\overline{R G})$ and control $\left(\overline{R G}_{C}\right)$ and the percentage RG (RG\%) was calculated as ratio between $\overline{R G}$ and $\bar{R} G_{C}$, as follows:

$R G \%=\frac{\overline{R G}}{\overline{R G}_{C}} \cdot 100$

2.3.3.3. Collembola tests. The collembola chronic bioassay was carried out using the common springtail (Folsomia candida) according to the ISO 17512-1 (2008) guideline. After preliminary bioassays that did not result in differences according to the concentrations, it was decided (also for practical and economic reasons) to use 100\% substrate soil concentration for all test samples (initial, intermediate, and final substrate soil). The test was carried out in glass containers with $10 \mathrm{~g}$ of test-substrate soil (dry weight). Ten specimens of $F$. candida were introduced into each container. At the beginning, deionized water and $10 \mathrm{mg}$ of dried baker's yeast were added to each container. Test containers were closed with parafilm and incubated at $20 \pm 2{ }^{\circ} \mathrm{C}$, in the dark, for 28 days. At the end, exposure mortality of adults was determined. As prescribed by the ISO 17512-1 (2008) guideline, four replicates were used. The survival percentage (Su) at Day 28 was considered the endpoint.

2.3.3.4. Nematodes tests. The bacterial feeding nematode Caenorhabditis elegans was maintained as a stock of dauer larvae (juvenile stage that occurs with a lack of food) on nematode growth medium agar (Brenner, 1974), according to standard procedures (Lewis and Fleming, 1995; Sulston and Hodgkin, 1988). The nematode bioassay with $C$. elegans was carried out according to standard methods (ASTM guidelines E2172, 2014 and to the principles of ISO 10872,2010 ). For the test, $0.5 \mathrm{~g}$ of each test-substrate (air-dry weight) was moistened with $0.35 \mathrm{~mL}$ of medium (containing $\mathrm{Na}_{2} \mathrm{HPO}_{4}, \mathrm{KH}_{2} \mathrm{PO}_{4}$, $\mathrm{NaCl}$, and $\mathrm{MgSO}_{4}$ ) in test wells and then mixed with Escherichia coli as the food supply. Ten first-stage juvenile nematodes were transferred to each test well (total of 160 nematodes). Their mean initial body length was $260 \pm 38 \mu \mathrm{m}$. Four replicates were set up for each test-soil substrate (initial, intermediate, and final) and the control. Even in this case only the concentration of $100 \%$ test-substrate soil was considered. In fact, as for $F$. candida, preliminary bioassays indicated no difference in the lower concentrations, thus for practical and economic reasons it was decided to use only the highest soil concentration. After $96 \mathrm{~h}$ of incubation at $20^{\circ} \mathrm{C}$, the test was stopped by heat killing the nematodes at $50{ }^{\circ} \mathrm{C}$, after checking the vitality of the specimens. The samples were then mixed with $0.5 \mathrm{~mL}$ of an aqueous solution of Rose Bengal to stain specimens for counting. Four different endpoints were considered: survival, growth, fertility, and reproduction. Survival percentage was considered also as the endpoint and was checked considering as alive the motile nematodes. Nematode growth was determined by measuring the body length at 100 -fold magnification using a light microscope. Growth was calculated by subtracting the mean initial body length of the test organisms from the mean body length after incubation. Nematode fertility was quantified by calculating the percentage of gravid organisms. Nematode reproduction was quantified by counting the number of eggs under a dissecting microscope at 75-fold magnification.

The second nematode toxicity test examined the direct exposure of one of the entomopathogenic nematodes (EPN) most used in biological control, which is also one of the most common species living in agricultural soil, Steinernema carpocapsae. Monoxenic infective juveniles in a $S$. carpocapsae culture (Becker Underwood, Ltd) were used for the bioassay. For the test, $0.5 \mathrm{~g}$ of each test-substrate soil (air-dry weight) was moistened with $0.35 \mathrm{~mL}$ of medium (containing $\mathrm{Na}_{2} \mathrm{HPO}_{4}, \mathrm{KH}_{2} \mathrm{PO}_{4}$, $\mathrm{NaCl}$, and $\mathrm{MgSO}_{4}$ ). The toxicity test was carried out according to ASTM guidelines E2172, 2014 and ISO 10872, 2010. The results were expressed as Su at $24 \mathrm{~h}$ and at $48 \mathrm{~h}$.

\subsection{Statistical analysis}

Statistical analysis was performed using Statgraphics ${ }^{\circledR}$ software. The responses to different substrate soil samples were compared by one-way analysis of variance. The F-test was used to assess whether there were significant differences amongst the means at the $95.0 \%$ confidence level ( $\mathrm{p}<0.05$ ); pairwise comparisons were assessed with the Tukey's honestly significant difference (HSD) procedure. 
Table 2

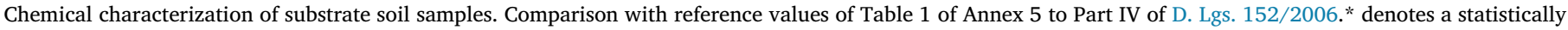
significant difference. Different apical characters indicate statistically significant differences among the samples.

\begin{tabular}{|c|c|c|c|c|c|c|}
\hline & $\begin{array}{l}\text { Reference values } \\
\text { column A (mg/ } \\
\text { kgTS) }\end{array}$ & $\begin{array}{l}\text { Reference values } \\
\text { column B (mg/ } \\
\text { kgTS) }\end{array}$ & $\begin{array}{l}\text { Initial substrate soil (mg/ } \\
\text { kgTS) }\end{array}$ & $\begin{array}{l}\text { Intermediate substrate soil } \\
(\mathrm{mg} / \mathrm{kgTS})\end{array}$ & $\begin{array}{l}\text { Final substrate soil (mg/ } \\
\text { kgTS) }\end{array}$ & p-value \\
\hline Cadmium & 2 & 15 & $0.2 \pm 0.0$ & $0.3 \pm 0.1$ & $0.3 \pm 0.1$ & 0.296 \\
\hline Cobalt & 20 & 250 & $8 \pm 1$ & $9 \pm 2$ & $11 \pm 1$ & 0.098 \\
\hline Total Chromium & 150 & 800 & $20 \pm 3^{\mathrm{X}}$ & $25 \pm 2^{X Y}$ & $28 \pm 2^{\mathrm{Y}}$ & $0.017^{*}$ \\
\hline Chromium VI & 2 & 15 & $<0.2$ & $<0.2$ & $<0.2$ & - \\
\hline Mercury & 1 & 5 & $<0.05$ & $<0.05$ & $<0.05$ & - \\
\hline Nickel & 120 & 500 & $18 \pm 3$ & $21 \pm 2$ & $23 \pm 2$ & 0.105 \\
\hline Iron $^{a}$ & - & - & $28884 \pm 758$ & $26718 \pm 969$ & $24903 \pm 1352$ & 0.072 \\
\hline Manganese $^{a}$ & - & - & $176 \pm 5$ & $170 \pm 7$ & $163 \pm 11$ & 0.422 \\
\hline Lead & 100 & 1000 & $19 \pm 2^{\mathrm{x}}$ & $25 \pm 3^{X Y}$ & $29 \pm 3^{Y}$ & $0.011^{*}$ \\
\hline Copper & 120 & 600 & $27 \pm 5^{\mathrm{x}}$ & $41 \pm 5^{Y}$ & $46 \pm 3^{Y}$ & $0.004^{*}$ \\
\hline Zinc & 150 & 1500 & $65 \pm 9^{x}$ & $81 \pm 9^{X Y}$ & $89 \pm 7^{Y}$ & $0.032^{*}$ \\
\hline Antimony & 10 & 30 & $<1$ & $<1$ & $<1$ & - \\
\hline Arsenic & 20 & 50 & $12 \pm 3$ & $13 \pm 3$ & $17 \pm 2$ & 0.113 \\
\hline Beryllium & 2 & 10 & $0.7 \pm 0.2$ & $0.7 \pm 0.1$ & $0.8 \pm 0.1$ & 0.629 \\
\hline Selenium & 3 & 15 & $14 \pm 2$ & $14 \pm 3$ & $15 \pm 2$ & 0.842 \\
\hline Thallium & 1 & 10 & $<0.2$ & $<0.2$ & $<0.2$ & - \\
\hline Vanadium & 90 & 250 & $31 \pm 3$ & $35 \pm 3$ & $37 \pm 4$ & 0.164 \\
\hline Cyanides & 1 & 100 & $<0.10$ & $<0.10$ & $<0.10$ & - \\
\hline Fluorides & 100 & 2000 & $<10$ & $<10$ & $<10$ & - \\
\hline Hydrocarbons $\mathrm{C}<12$ & 10 & 2000 & $<0.05$ & $<0.05$ & $<0.05$ & - \\
\hline Hydrocarbons $\mathrm{C}>12$ & 50 & 2000 & $<10$ & $<10$ & $<10$ & - \\
\hline Aromatic hydrocarbons & $0.1-1$ & $2-100$ & $<0.001$ & $<0.001$ & $<0.001$ & - \\
\hline Aromatic polycyclic hydrocarbons & $0.5-5$ & $5-50$ & $<0.01$ & $<0.01$ & $<0.01$ & - \\
\hline $\begin{array}{l}\text { Aliphatic chlorinated carcinogenic } \\
\text { hydrocarbons }\end{array}$ & $0.01-1$ & $0.1-20$ & $<0.001$ & $<0.001$ & $<0.001$ & - \\
\hline $\begin{array}{l}\text { Aliphatic chlorinated non- } \\
\text { carcinogenic hydrocarbons }\end{array}$ & $0.3-1$ & $5-50$ & $<0.001$ & $<0.001$ & $<0.001$ & - \\
\hline $\begin{array}{l}\text { Aliphatic halogenated } \\
\text { carcinogenic hydrocarbons }\end{array}$ & $0.01-0.5$ & $0.1-10$ & $<0.001$ & $<0.001$ & $<0.001$ & - \\
\hline Nitrobenzene & $0.1-0.5$ & $10-30$ & $<0.01$ & $<0.01$ & $<0.01$ & - \\
\hline Chlorobenzene & $0.05-1$ & $10-50$ & $<0.001$ & $<0.001$ & $<0.001$ & - \\
\hline Phenol & 1 & 60 & $0.039 \pm 0.018$ & $0.018 \pm 0.012$ & $0.017 \pm 0.011$ & 0.175 \\
\hline Methylphenol (o-, m-, p-) & 0.1 & 25 & $0.0079 \pm 0.001^{\mathrm{x}}$ & $0.0051 \pm 0.001^{\mathrm{Y}}$ & $0.0059 \pm 0.001 \mathrm{XY}$ & $0.034^{*}$ \\
\hline Chlorinated phenols & $0.01-0.5$ & $12-50$ & $<0.001$ & $<0.001$ & $<0.001$ & - \\
\hline Aromatic amines & $0.05-0.5$ & $13-50$ & $<0.01$ & $<0.01$ & $<0.01$ & - \\
\hline Esters of phthalic acid & 10 & 2000 & $<1.0$ & $<1.0$ & $<1.0$ & - \\
\hline
\end{tabular}

a Table 1 of Annex 5 to Part IV of D. Lgs. 152/2006 does not specify any reference value for Iron and Manganese.

\section{Results and discussion}

\subsection{Substrate soil chemical characterization}

The results of the chemical characterization are reported in Table 2 and were compared with the reference values from Italian legislation for soil contamination (Table 1 of Annex 5 to Part IV of D. Lgs. 152/ 2006). Statistical analysis revealed a statistically significant increase (from the initial substrate soil samples to the final ones) of the following chemical species: total chromium, lead, copper, zinc. However, treatment-related overall build-up of heavy metals spanned conditions from negligible to acceptable because concentrations remained well within the limits for residential soil. The concentration of each chemical element was always below the reference values, even in the final substrate soil, with the only exception being selenium. The concentration of this element exceeded the reference value of column A (screening values for public, private, and residential green areas), but remained below the corresponding reference value of column B (screening values for commercial and industrial activities). But it must be noted that selenium was above the reference value of column A even in the initial substrate soil and no change of concentration was recorded throughout the experiment. The initial substrate soil samples were collected before the beginning of the phytotreatment tests; therefore, the abnormal concentration of this element cannot be related to the leachate irrigation procedure, but rather to the characteristics of the locally available soil utilized in the experiment.

\subsection{Substrate soil ecotoxicological characterization}

\subsubsection{Lepidium sativum bioassay}

The GI\% of $L$. sativum is shown in Fig. 2. Focusing on the results referred to deionized water as control (Fig. 2A,B,C), similar trends were detected for the three substrate soils for concentrations between 2 and $10 \%$, characterised by peaks of the GI\% up to $180 \%$ (Fig. 2B). For concentrations higher than $10 \%$, the GI\% of the initial substrate soil presented a slightly decreasing trend but remained always above $80 \%$ (Fig. 2A). The other samples presented some fluctuations, which were more marked for the intermediate substrate soil. For the intermediate sample, GI\% ranged between 140 and 160\% (Fig. 2B), while for the final sample, the GI\% ranged between 100 and $120 \%$ (Fig. 2C). The trends of the GI\% referred to controls in which artificial soil and deionized water were used are similar (Fig. 2D, E, F), especially for concentrations higher than $10 \%$. In fact, the GI\% decreased but remained above $50 \%$ for the initial soil (Fig. 2D), between 75 and $100 \%$ for the intermediate soil (Fig. 2E), and between 90 and 110\% for the final substrate soil (Fig. 2F). Statistical analysis was performed on the results of the bioassays in which $100 \%$ test-soil substrate was used, in order to mimic the real scale conditions in which the substrate is not mixed with artificial soil (Supplementary material - Table S2). It revealed a statistically significant increase of the GI\% between initial and intermediate substrate soil, and between initial and final substrate soil, respectively. The higher values of the GI\% of intermediate and final samples could be due to an increased concentration of nutrients (especially nitrogen) in the substrate soil, compared to the initial 
A

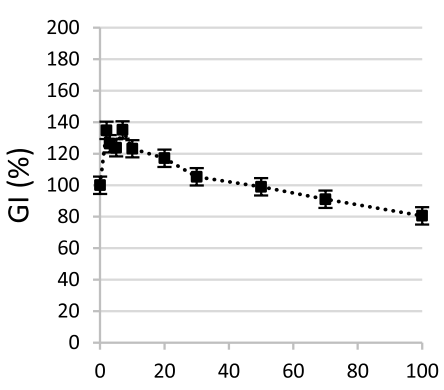

D

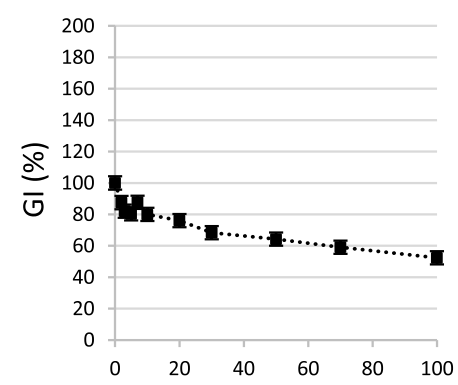

B

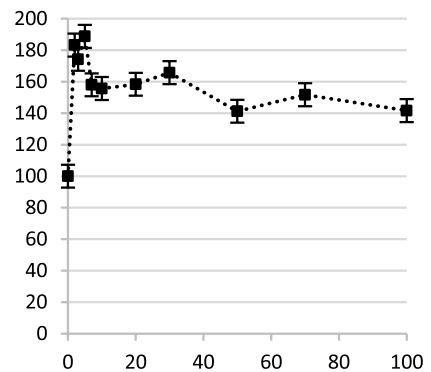

Testing substrate soil concentration (\%)

E

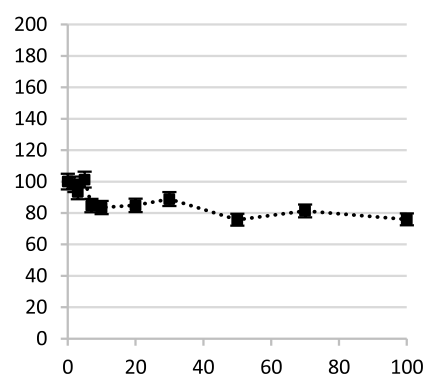

C

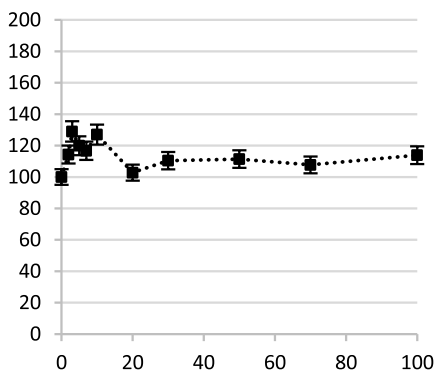

F

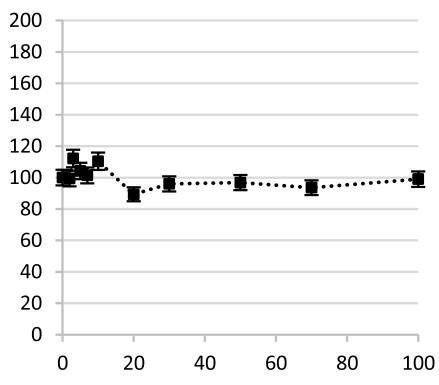

Testing substrate soil concentration (\%)

Fig. 2. Results of the percentage Germination Index (GI\%) for initial (A), intermediate (B), and final (C) substrate soil with deionized water as control; results of the GI\% for initial (D), intermediate (E), and final (F) substrate soil with artificial soil and deionized water as control. Deviation bars refer to the $95 \%$ confidence level.

sample. The increase of nitrogen and phosphorous content during the phytotreatment lab-scale tests is reported in Table 3. The maximum increase of the nitrogen content was $13 \%$ ( $\Delta$ Final-Initial): it seemed to have a great influence on the cress development, although a statistically significant increase was not detected. The phosphorus concentration result was always below the detection limits. Summarizing, it is possible to affirm that the germination of Lepidium sativum did not present anomalies (e.g. phytotoxicity phenomena) induced by leachate application and the phytotreatment process.

\subsubsection{Earthworm bioassay}

Results of $E$. fetida earthworms percentage Relative Survival (RS\%) and percentage Relative Growth (RG\%) are reported in Fig. 3. Relative Survival close to $100 \%$ was detected for all three substrate soils, independent of the concentrations, meaning that almost all the earthworms remained alive in the initial, intermediate, and final substrate soils. Focusing on the lowest values, a minimum $90 \%$ of Relative Survival was observed with $5 \%$ of initial substrate soil (Fig. 3A), a minimum $85.7 \%$ of $\mathrm{RS} \%$ with $2 \%$ of intermediate substrate soil (Fig. 3B) and a minimum $92.9 \%$ of RS\% with $3 \%$ and $70 \%$ of final substrate soil (Fig. 3C). In the assays with the final substrate soil, some values exceeded $100 \%$, indicating that survival of earthworms was even higher than in the controls, in which artificial soil, described in the OECD Guideline 222/2004 as optimal for the earthworms, was used.

Statistical analysis was applied to the results of the bioassays in which $100 \%$ test-soil substrate was used (Supplementary material Table S3) and did not reveal any significant difference among the different substrate soil samples (initial, intermediate, final).

The RG\% increased with increasing concentrations of initial substrate soil, reaching a maximum value equal to approximately $200 \%$ (Fig. 3D) for concentrations of test samples with greater than $30 \%$ testsubstrate soil. With regards to the intermediate and final substrate soils (Fig. 3E and F), after an initial increase, the trends of the RG\% decreased with increasing concentration of the test substrate soils but were never below $100 \%$, which is the value of the control. Statistical analysis was applied again to the results of the bioassays in which $100 \%$ test-soil substrate was used (Supplementary material - Table S3), revealing a statistically significant decrease of the RG\% between initial and intermediate substrate soil, and between of initial and final substrate soil, respectively, clearly visible also in Fig. 3. However, RG\% was always above $100 \%$, the value of the control, in which artificial soil, specifically prepared the ensure optimal growing conditions, was used. Therefore, similarly to the $L$. sativum bioassays, the tests performed with E. fetida earthworms did not reveal anomalies which could be related to the applied process of phytotreatment.

\subsubsection{Collembola bioassay}

Endpoints results of toxicity tests on $F$. candida, expressed as Survival (Su), were compared with the corresponding control in which $100 \%$ Su was observed.

The average Su in the intermediate substrate soil (94.75\%) was higher than the Su for the initial soil sample (92.50\%); Su decreased to $90.50 \%$ in the final sample. These minimal variations of the Su were not statistically significant (Supplementary material - Table S4) and were

Table 3

Nitrogen and phosphorous content in the substrate soils (initial, intermediate, and final) used for the experiments.

\begin{tabular}{|c|c|c|c|c|c|c|}
\hline & Initial (\%) & Intermediate (\%) & Final (\%) & p-value & $\Delta$ Intermediate-Initial (\%) & $\Delta$ Final-Initial (\%) \\
\hline Nitrogen content & $0.15 \pm 0.1$ & $0.16 \pm 0.1$ & $0.17 \pm 0.1$ & 0.1250 & 7 & 13 \\
\hline Phosphorous content & $<0.05$ & $<0.05$ & $<0.05$ & - & - & - \\
\hline
\end{tabular}


A

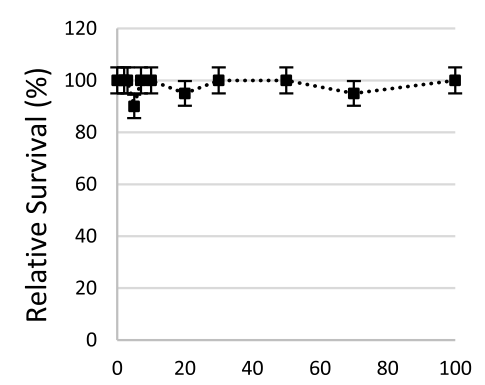

$\mathrm{D}$

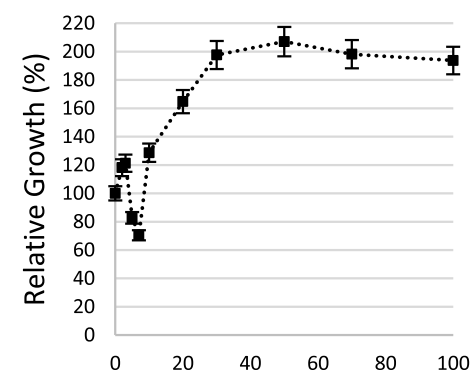

B

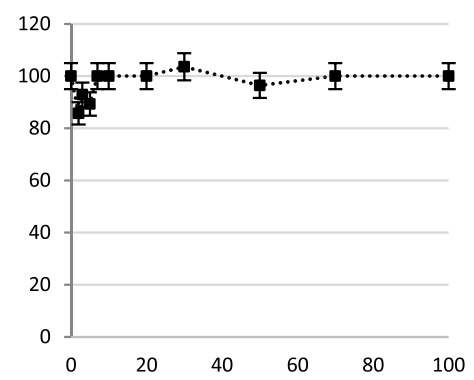

$\mathrm{C}$

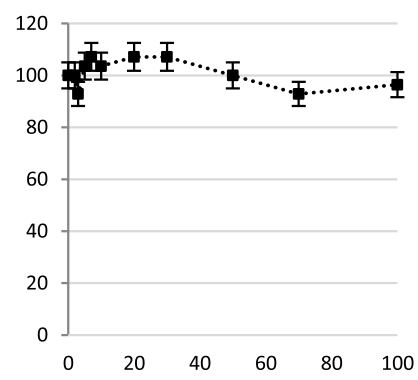

Testing substrate soil concentration (\%)

$\mathrm{E}$

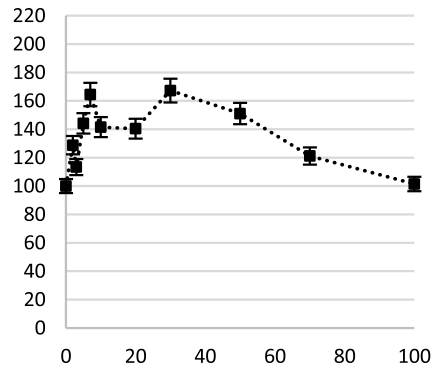

Testing substrate soil concentration (\%)

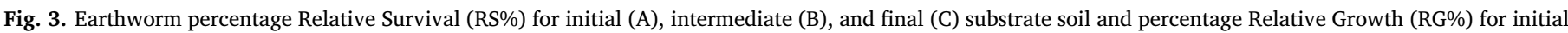
(D), intermediate (E), and final (F) substrate soil. Deviation bars refer to the $95 \%$ confidence level.

not likely related to the applied phytotreatment process: the values of the intermediate and final samples are very close to the Su of the initial substrate soil, but the latter was sampled before the start of the test.

\subsubsection{C. elegans and S. carpocapsae nematode bioassays}

Results of the ecotoxicity tests on the nematodes $C$. elegans and $S$. carpocapsae are reported in Table 4. As already noticed for the F. candida assays, minimal variations (not statistically significant) were detected for all the endpoints considered (survival, growth, fertility, and reproduction) among the three substrate soils. Again, these minimal variations were not likely related to the applied phytotreatment process.

\section{Conclusions}

The aim of this study was to provide a contribution to the current Italian legislation regarding the properties of the substrate soil used for the leachate phytotreatment process on the top of closed landfills. The results of the chemical analyses were compared to the reference values for soil contamination. Almost all the parameters were below the reference values, except for selenium, which exceeded the reference even in the initial sample. The tests on earthworms did not present any critical results; in fact, the survival percentages remained close to $100 \%$ and the growth results were equal or even higher than the control value, especially in intermediate and final substrate soil samples. The same consideration is valid for the bioassays in which $L$. sativum was used, which did not show significant variations in the Germination Index trend. The four endpoints of the nematode C. elegans (survival, growth, fertility, and reproduction) and the survival percentage results of the springtail $F$. candida and nematode $S$. carpocapsae also demonstrated that the three sample types did not affect the behaviour of these invertebrates.

The minimal quantity of contaminants detected in the substrate soil at the end of the test could be linked to phytotreatment activity by the sunflowers but further studies are required to understand the pathways of contaminants removal (e.g.: plants uptake, microbial degradation).

The results of this research indicate that phytotreatment on the top of closed landfills is a feasible option for in-situ leachate management. However, it is important to implement additional researches, for example by changing the quality of the leachate, the quality of the substrate soil, and by increasing the number of model and focal species in the ecotoxicological tests.

Table 4

C. elegans and S. carpocapsae nematode average endpoint results.

\begin{tabular}{|c|c|c|c|c|c|c|}
\hline & & Control & Initial substrate soil & Intermediate substrate soil & Final substrate soil & p-value \\
\hline \multirow[t]{4}{*}{ C. elegans } & Survival (\%) & $100 \pm 0$ & $99.25 \pm 0.9$ & $99.75 \pm 0.5$ & $99.50 \pm 1$ & 0.716 \\
\hline & Growth $(\mu \mathrm{m})$ & $1325 \pm 64$ & $1275 \pm 28$ & $1313 \pm 62$ & $1350 \pm 57$ & 0.181 \\
\hline & Fertility (\%) & $100 \pm 0$ & $91.50 \pm 5.9$ & $96.75 \pm 5.1$ & $96.50 \pm 5.1$ & 0.250 \\
\hline & Reproduction ( $\mathrm{N}^{\circ}$ egg/female) & $22.25 \pm 1.7$ & $19.00 \pm 1.4$ & $21.25 \pm 1.7$ & $20.75 \pm 0.9$ & 0.108 \\
\hline \multirow[t]{2}{*}{ S. carpocapsae } & Survival at $24 \mathrm{~h}(\%)$ & $100 \pm 0$ & $95.25 \pm 3.3$ & $94.00 \pm 3.5$ & $95.00 \pm 3.6$ & 0.900 \\
\hline & Survival at $48 \mathrm{~h}(\%)$ & $100 \pm 0$ & $91.00 \pm 4.2$ & $89.00 \pm 3.5$ & $92.00 \pm 3.1$ & 0.608 \\
\hline
\end{tabular}




\section{Funding}

This work was supported by the ROLES, cooperation project between Italy and China on Remediation of Old Landfills for Environmental Sustainability.

\section{Acknowledgements}

We would like to thank Dr. Tiziano Bonato for his help with the chemical analysis.

\section{Appendix A. Supplementary data}

Supplementary data to this article can be found online at https:// doi.org/10.1016/j.jenvman.2018.10.014.

\section{References}

Agostini, E., Coniglio, M.S., Milrad, S.R., Tigier, H.A., Giulietti, A.M., 2003. Phytoremediation of 2,4-dichlorophenol by Brassica napus hairy root cultures. Biotechnol. Appl. Biochem. 37, 139-144.

Akinbile, C.O., Yusoff, M.S., Zuki, A.Z.A., 2012. Landfill leachate treatment using subsurface flow constructed wetland by Cyperus haspan. Waste Manag. 32, 1387-1393.

APAT, 2004. Agenzia per la Protezione dell'Ambiente e per i servizi Tecnici (Italian Environmental Protection Agency). Guida tecnica su metodi di analisi per il suolo e i siti contaminati - utilizzo di indicatori biologici ed ecotossicologici. http://www. isprambiente.gov.it/files/biodiversita/APAT_Guida_tecnica_indicatori_2002.pdf, Accessed date: 27 November 2017.

ASTM E2172, 2014. Standard Guide for Conducting Laboratory Soil Toxicity Tests with the Nematode Caenorhabditis elegans. American Society for Testing and Materials, Westconshohocken, PA, USA.

Bouyoucos, G.J., 1962. Hydrometer method improved for making particle size analyses of soils. Agron. J. 54, 464-465.

Brenner, S., 1974. The genetics of Caenorhabditis elegans. Genetics 77, 71-94.

Brunetti, G., Farrag, K., Rovira, P.S., Nigro, F., Senesi, N., 2011. Greenhouse and field studies on $\mathrm{Cr}, \mathrm{Cu}, \mathrm{Pb}$ and $\mathrm{Zn}$ phytoextraction by Brassica napus from contaminated soils in the Apulia region, Southern Italy. Geoderma 160, 517-523.

CNR-IRSA, 2003. Consiglio Nazionale delle Ricerche - Istituto di Ricerca sulle Acque. Metodi Analitici sulle Acque. Quaderno 29/2003 VV. pp. 1-2.

Cossu, R., Williams, I.D., 2015. Urban mining: concepts, terminology, challenges. Waste Manag. 45, 1-3.

Dawson, J.J.C., Godsiffe, E.J., Thompson, I.P., Ralebitso-Senior, T.K., Killhaml, K.S., Paton, G.I., 2007. Application of biological indicators to assess recovery of hydrocarbon impacted soils. Soil Biol. Biochem. 39, 164-177.

D. Lgs. 36/2003 (Italian Legislative Decree 36/2003). Attuazione della direttiva 1999/ 31/CE relativa alle discariche di rifiuti. http://www.camera.it/parlam/leggi/ deleghe/03036dl.htm (accessed 29 January 2018).

D. Lgs. 152/2006 (Italian Legislative Decree 152/2006). Norme in materia ambientale. http://www.camera.it/parlam/leggi/deleghe/06152dl.htm (accessed 2 February 2018).

DGR Lombardia n. X/2461/2014 (Lombardy Region Decree X/2461). Linee guida per la progettazione e gestione sostenibile delle discariche.http://download.acca.it/BibLusnet/OpereEdili/LineeGuida_Lombardia_Discariche.pdf (accessed 2 February 2018).

Di Maria, F., Sisani, F., 2017. Replacing energy crops with bio-waste for an existing anaerobic digestion plant: energetic and carbon footprint in a LCA perspective. Energy Procedia 126, 377-384.

Di Maria, F., Sisani, F., Contini, S., Ghosh, S.K., 2018. Impact of different schemes for treating landfill leachate. Waste Manag. 71, 255-266.

EFSA, Panel on Plant Protection Products and their Residues, 2017. Scientific Opinion addressing the state of the science on risk assessment of plant protection products for in-soil organisms. EFSA J. 15, 4690.

EU Directive 1999/31/CE European Directive on the Landfill of Waste. http://eur-lex. europa.eu/legal-content/EN/TXT/?uri = CELEX:31999L0031, Accessed date: 3 February 2018

Fraser, L.H., Carty, S.M., Steer, D., 2004. A test of four plant species to reduce total nitrogen and total phosphorus from soil leachate in subsurface wetland microcosms. Bioresour. Technol. 94, 185-192.

Garbo, F., Lavagnolo, M.C., Malagoli, M., Schiavon, M., Cossu, R., 2017. Different leachate phytotreatment systems using sunflowers. Waste Manag. 59, 267-275.

Hasselgren, K., 1992. Soil-plant treatment system. In: Christensen, T.H., Cossu, R., Stegmann, R. (Eds.), Landfilling of Waste: Leachate. CRC press, pp. 361-380.

Hennebert, P., 2017. Proposal of concentration limits for determining the hazard property HP 14 for waste using ecotoxicological tests. Waste Manag. https://doi.org/10. 1016/j.wasman.2017.11.048.

Holmstrup, M., Bindesbøl, A., Oostingh, G.J., Duschl, A, A., Scheil, V., Köhler, H., Loureiro, S., Soares, A.M.V.M., Ferreira, A.L.G., Kienle, C., Gerhardt, A., Laskowski, R., Kramarz, P.E., Bayley, M., Svendsen, C., Spurgeon, D.J., 2010. Interactions between effects of environmental chemicals and natural stressors: a review. Sci. Total
Environ. 408, 3746-3762

ISO 10872, 2010. Water quality - Determination of the toxic effect of sediment and soil samples on growth, fertility and reproduction of Caenorhabditis elegans (Nematoda). https://www.iso.org/standard/46253.html, Accessed date: 15 November 2017.

ISO 11274 , 1998. Soil quality - Determination of the water-retention characteristic Laboratory methods. https://www.iso.org/standard/19252.html, Accessed date: 20 November 2017.

ISO 17512-1, 2008. Soil quality - Avoidance test for determining the quality of soils and effects of chemicals on behavior, pt 1: test with earthworms (Eisenia fetida and Eisenia andrei). https://www.iso.org/standard/38402.html, Accessed date: 24 October 2017.

Jacomini, C., Nappi, P., Sbrilli, G., Mancini, L., 2000. Indicatori ed indici ecotossicologici e biologici applicati al suolo: stato dell'arte. Agenzia Nazionale per la Protezione dell'Ambiente. http://ctntes.arpa.piemonte.it/pubblicazioni/RTI_CTN_SSC_3_2000. pdf, Accessed date: 29 October 2017.

January, M.C., Cutright, T.J., Van Keulen, H., Wei, R., 2008. Hydroponic phytoremediation of $\mathrm{Cd}, \mathrm{Cr}, \mathrm{Ni}, \mathrm{As}$, and Fe: can Helianthus annuus hyperaccumulate multiple heavy metals? Chemosphere 70, 531-537.

Lavagnolo, M.C., Malagoli, M., Alibardi, L., Garbo, F., Pivato, A., Cossu, R., 2017. Use of oleaginous plants in phytotreatment of grey water and yellow water from source separation of sewage. J. Environ. Sci. 55, 274-282.

Lavagnolo, M.C., Malagoli, M., Garbo, F., Pivato, A., Cossu, R., 2016. Lab-scale phyto treatment of old landfill leachate using different energy crops. Waste Manag. 55, 265-275.

Lewis, J.A., Fleming, J.T., 1995. Basic culture methods. Methods Cell Biol. 48, 3-29.

Ma, J., Hipel, K.W., 2016. Exploring social dimensions of municipal solid waste management around the globe - a systematic literature review. Waste Manag. 56, 3-12.

Ma, Y., Rajkumar, M., Zhang, C., Freitas, H., 2016. Beneficial role of bacterial endophytes in heavy metal phytoremediation. Environ. Manag. 174, 14-25.

Manachini, B., Corsini, A., Bocchi, S., 2009. Soil quality indicators as affected by a long term barley-maize and maize cropping systems. Ital. J. Agron. 4, 5-22.

Marchiol, L., Fellet, G., Perosa, D., Zerbi, G., 2007. Removal of trace metals by Sorghum bicolour and Heliantus annus in a site polluted by industrial wastes: a field experience. Plant Physiol. Biochem. 45, 379-387.

OECD, 2004. OECD 222/2004: guidelines for the testing of chemicals. Earthworm reproduction test (Eisenia fetida/Eisenia andrei). https://doi.org/10.1787/ 9789264070325-en, Accessed date: 10 January 2010.

Oloibiri, V., Chys, M., De Wandel, S., Demesteere, K., Van Hulle, S.W.H., 2017. Removal of organic matter and ammonium from landfill leachate through different scenarios: operational cost evaluation in a full-scale case study of a Flemish landfill. J. Environ. Manag. 203, 774-781.

Pandey, V.C., Bajpai, O., Singh, N., 2016. Energy crops in sustainable phytoremediation. Renew. Sustain. Energy Rev. 54, 58-73.

Pivato, A., Garbo, F., Moretto, M., Lavagnolo, M.C., 2018a. Energy crops on landfills: functional, environmental, and costs analysis of different landfill configurations. Environ. Sci. Pollut. Res. https://doi.org/10.1007/s11356-018-1452-1.

Pivato, A., Lavagnolo, M., Manachini, B., Raga, R., Beggio, G., Vanin, S., 2018b. Acute toxicity tests using earthworms to estimate ecological quality of compost and digestate. J. Mater. Cycles Waste Manag. 20, 552-560.

Pivato, A., Lavagnolo, M.C., Manachini, B., Vanin, S., Raga, R., Beggio, G., 2017. Ecological risk assessment of agricultural soils for the definition of soil screening values: a comparison between substance-based and matrix-based approaches. Heliyon 3, e00284.

Pivato, A., Raga, R., Vanin, S., Rossi, M., 2014. Assessment of compost quality for its environmentally safe use by means of an ecotoxicological test on a soil organism. J. Mater. Cycles Waste Manag. 16, 763-774.

Pivato, A., Vanin, S., Raga, R., Lavagnolo, M.C., Barausse, A., Rieple, A., Laurent, A., Cossu, R., 2016. Use of digestate from a decentralized on-farm biogas plant as fertilizer in soils: an ecotoxicological study for future indicators in risk and life cycle assessment. Waste Manag. 49, 378-389.

Saleem, M., Spagni, A., Alibardi, L., Bertucco, A., Lavagnolo, M.C., 2018. Assessment of dynamic membrane filtration for biological treatment of old landfill leachate. J. Environ. Manag. 213, 27-35.

Schnoor, J.L., Light, L.A., McCutcheon, S.C., Wolfe, N.L., Carreia, L.H., 1995. Phytoremediation of organic and nutrient contaminants. Environ. Sci. Technol. 29, 318A-323A.

Stottmeister, U., Weißner, A., Kuschk, P., Kappelmeyer, U., Kästner, M., Bederski, O., Müller, R.A., Moormann, H., 2003. Effects of plants and microorganisms in constructed wetlands for wastewater treatment. Biotechnol. Adv. 22, 93-117.

Sulston, J.E., Hodgkin, J., 1988. Methods. In: Wood, W.B. (Ed.), The Nematode Caenorhabditis elegans. Cold Spring Harbor Laboratory Press, pp. 587-606.

Tang, X., Li, Q., Wu, M., Lin, L., Scholz, M., 2016. Review of remediation practices regarding cadmium-enriched farmland soil with particular reference to China. J. Environ. Manag. 181, 646-662.

USDA-NRCS, 1999. Soil taxonomy. In: second ed. Agricultural Handbook, vol. 436.

USEPA, 2005. Guidance for Developing Ecological Soil Screening Levels, Office of Solid Waste and Emergency Response. United States Environmental Protection Agency, Washington, USA. https://nepis.epa.gov/EPA/html/DLwait.htm?url=/Exe/ZyPDF, cgi/P100CDCG.PDF?Dockey = P100CDCG.PDF, Accessed date: 10 January 2018.

Verakoon, G.M.P.R., Jinadasa, K.B.S.N., Herath, G.B.,B., Mowjood, M.I.M., van Bruggen, J.J.A., 2013. Impact of the hydraulic loading rate on pollutants removal in tropical horizontal subsurface flow constructed wetlands. Ecol. Eng. 61, 154-160. 